\title{
Adsorption Capacity for Phosphorus Comparison among Activated Alumina, Silica Sand and Anthracite Coal
}

\author{
Junling WANG ${ }^{1,2, *}$, Yajun ZHANG ${ }^{2}$, Cuimin FENG ${ }^{2}$, Junqi LI $^{2}$, Guibai LI ${ }^{1}$ \\ ${ }^{1}$ School of Municipal and Environmental Engineering, Harbin Institute of Technology, Harbin, China \\ ${ }^{2}$ School of Environment and Energy Engineering, BUCEA, Beijing, China \\ E-mail: wangjunling@bucea.edu.cn
}

Received June 27, 2009; revised July 26, 2009; accepted September 3, 2009

\begin{abstract}
Experimental researches on adsorptive capacity of activated alumina, silica sand and anthracite coal for phosphorus were conducted. Results showed that performances of three filter media were all in line with Langmuir isotherm, and activated alumina adsorptive performance was much better than silica sand and anthracite coal for phosphorus removal. The adsorptive capacity of activated alumina, silica sand and anthracite coal for phosphorus was $3333 \mu \mathrm{g} / \mathrm{g}, 49 \mu \mathrm{g} / \mathrm{g}$ and $100 \mu \mathrm{g} / \mathrm{g}$ respectively. Activated alumina displayed adsorptive function well for phosphorus, because its inner porosity, specific surface area and surface isoelectric $\mathrm{pH}$ value were all higher than those of other two filter media. While activated alumina was used as filter material in water treatment process, phosphorus would be removed strongly because of adsorptive characteristic of activated alumina.
\end{abstract}

Keywords: Activated Alumina, Filtration, Adsorptive Capacity, Phosphorus Removal

\section{Introduction}

Generally the proportion of organic carbon, nitrogen and phosphorus is 100:10:1 for microorganism growing in pipe water, therefore, removal of phosphorus as a kind of nutrient in drinking water may be a method to restrain the regrowth of microorganism. Lehtola [1,2] reported that phosphorus could replace the organic matter as the limitation factor for microbial regrowth in drinking water with high organic matter concentration. In China, a great many surface water sources have been contaminated severely by organic matter, thus the phosphorus will be the limitation factor in drinking water and raw water there.

Many researchers have studied the removal technology for phosphorus in drinking water. Membrane treatment technology [3] and ozonation process [4] were two techniques that have been tested to remove phosphorus in drinking water, but removal rate did not get promoted. In addition, researchers $[5,6]$ experimented and concluded that traditional water treatment process in water plant couldn't achieve efficient performance for phosphorus removal. It is unknown whether traditional filter media hold strong adsorptive capacity for phosphorus or not. New technique and application of new filter media to improve the removal of phosphorus were creative and beneficial explored for keeping drinking water biological stability. Activated alumina was one unique media with high adsorptive capacity for many pollutants, but the character for phosphorus removal in drinking water has not been disclosed, so it is worth testing and confirming the efficiency to remove or adsorb phosphorus, at the same time, adsorptive capacity of traditional filter media silica sand and anthracite coal are tested to compare, moreover, application feasibility of activated alumina should be considered.

\section{Experimental Materials and Methods}

\subsection{Experimental Materials}

Three filter media including activated alumina, silica sand and anthracite coal were utilized in experiments. Silica sand and anthracite coal were mostly used in filtration process of water works. All materials purchased in local market showed the characteristics in Table 1.

The appliance used in experimentation included beaker flask, constant temperature oscillator, $0.45 \mu \mathrm{m}$ 
Table 1. Physical characteristics of filter media.

\begin{tabular}{lccc}
\hline \multicolumn{1}{c}{ Item } & Activated alumina & Silica sand & Anthracite coal \\
\hline $\begin{array}{l}\text { Granular } \\
\text { size }(\mathrm{mm})\end{array}$ & 1.2 & $0.5 \sim 1.25$ & $1 \sim 1.8$ \\
density $\left(\mathrm{g} / \mathrm{cm}^{3}\right)$ & 1.04 & 2.64 & 1.6 \\
porosity $(\%)$ & 44.9 & 43.1 & 52.7 \\
\hline
\end{tabular}

microporous membranes, and main chemical was $\mathrm{KH}_{2} \mathrm{PO}_{4}$.

\subsection{Experimental Methods}

Step one, $\mathrm{KH}_{2} \mathrm{PO}_{4}$ was dissolved into ultrapure water to form samples with various phosphorus concentration in five beaker flasks, and each volume was $1000 \mathrm{~mL}$. Phosphorus concentration of prepared water in beaker flasks were $500 \mu \mathrm{g} / \mathrm{L}, 2000 \mu \mathrm{g} / \mathrm{L}, 5000 \mu \mathrm{g} / \mathrm{L}, 8000 \mu \mathrm{g} / \mathrm{L}, 10000 \mu \mathrm{g} / \mathrm{L}$ respectively. Step two, $5 \mathrm{~g}$ activated alumina filter media was added to every beaker flask and put into constant temperature oscillator. After operating for $24 \mathrm{~h}$ at 40 degree Celsius, samples in all beaker flasks were filtered through $0.45 \mu \mathrm{m}$ membrane, the phosphorus concentration in supernatant was examined and adsorptive capacity value was obtained.

Experimental procedure with silica sand and anthracite coal were as same as activated alumina, but phosphorus concentration varied. It was conjectured that adsorptive capacities of silica sand and anthracite coal were all lower than activated alumina, so experimental initial concentration was set at low level. Six water samples with phosphorus concentration $100 \mu \mathrm{g} / \mathrm{L}, 200 \mu \mathrm{g} / \mathrm{L}$, $300 \mu \mathrm{g} / \mathrm{L}, 500 \mu \mathrm{g} / \mathrm{L}, 800 \mu \mathrm{g} / \mathrm{L}$, and $1000 \mu \mathrm{g} / \mathrm{L}$ were prepared for silica sand experiment, and $50 \mu \mathrm{g} / \mathrm{L}, 100 \mu \mathrm{g} / \mathrm{L}$, $200 \mu \mathrm{g} / \mathrm{L}, 300 \mu \mathrm{g} / \mathrm{L}, 500 \mu \mathrm{g} / \mathrm{L}$, and $1000 \mu \mathrm{g} / \mathrm{L}$ for anthracite coal. Silica sand and anthracite coal were added by $5 \mathrm{~g}$ respectively.

\section{Results}

\subsection{Experiment on Phosphorus Adsorption by Activated Alumina}

The formula is:

$$
q_{e}=\frac{x}{m}=\frac{V\left(C_{i}-C_{e}\right)}{m}
$$

where $x=$ quality of adsorbed adsorbate, $\mu \mathrm{g}$

$m=$ quality of adsorbent, $\mathrm{g}$

$V=$ volume of water sample, $\mathrm{L}$

$C_{i}=$ the initial concentration of adsorbate, $\mu \mathrm{g} / \mathrm{L}$

$C_{e}=$ equilibrium concentration of adsorbate, $\mu \mathrm{g} / \mathrm{L}$

$q_{e}=$ adsorptive capacity, $\mu \mathrm{g} / \mathrm{g}$

Experimental result was presented in Table 2 and plotted in Figure 1.
In view of the variation of the isotherm, it seems to obey the Langmuir isotherm. The adsorption equations are:

$$
\begin{gathered}
\mathrm{q}_{\mathrm{e}}=\frac{\mathrm{x}}{\mathrm{m}}=\frac{V\left(\mathrm{C}_{\mathrm{i}}-\mathrm{C}_{\mathrm{e}}\right)}{\mathrm{m}}=\mathrm{b}\left(\mathrm{q}_{\mathrm{e}}\right)^{0} \frac{C_{e}}{1+b C_{e}} \\
\frac{C_{\mathrm{e}}}{q_{e}}=\frac{1}{\left(q_{e}\right)^{0}} C_{\mathrm{e}}+\frac{1}{\mathrm{~b}\left(\mathrm{q}_{\mathrm{e}}\right)^{0}}
\end{gathered}
$$

where $\mathrm{b}=$ constant value

$\left(q_{e}\right)^{0}=$ adsorptive capacity extreme value, $\mu \mathrm{g} / \mathrm{g}$

Taking the $C_{e}$ as x-axis and $C_{e} / q_{e}$ as y-axis, Langmuir formula was plotted in Figure 2. Then

Table 2. Adsorption experimental result for phosphorus by activated alumina.

\begin{tabular}{cccc}
\hline $\begin{array}{c}\text { Initial } \\
\text { Concentration } \\
\mathrm{C}_{\mathrm{i}}(\mu \mathrm{g} / \mathrm{L})\end{array}$ & $\begin{array}{c}\text { Equilibrium } \\
\text { Concentration } \\
\mathrm{C}_{\mathrm{e}}(\mu \mathrm{g} / \mathrm{L})\end{array}$ & $\begin{array}{c}\text { Adsorptive } \\
\text { Capacity } \\
\mathrm{q}_{\mathrm{e}}(\mu \mathrm{g} / \mathrm{g})\end{array}$ & $\mathrm{C}_{\mathrm{e}} / \mathrm{q}_{\mathrm{e}}$ \\
\hline 500 & 56.32 & 88.74 & 0.63 \\
2000 & 236.54 & 352.69 & 0.67 \\
5000 & 723.83 & 855.23 & 0.85 \\
8000 & 1452.49 & 1309.50 & 1.11 \\
10000 & 2038.34 & 1592.33 & 1.28 \\
\hline
\end{tabular}

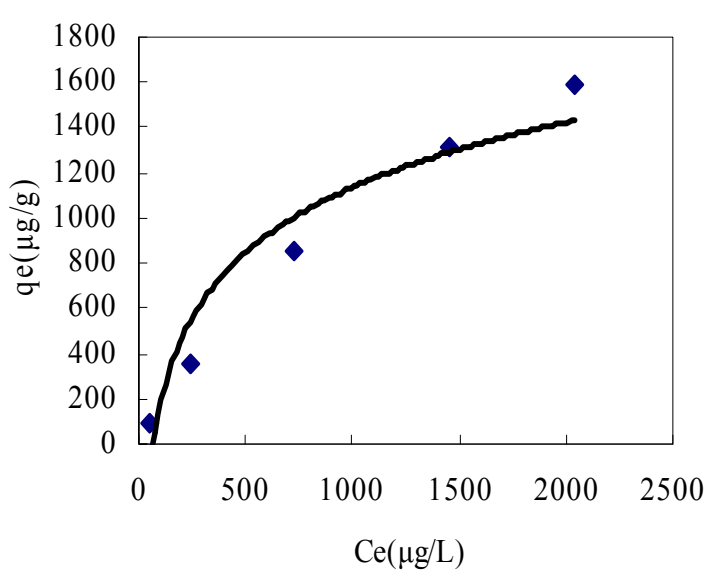

Figure 1. Phosphorus adsorption isotherm of activated alumina.

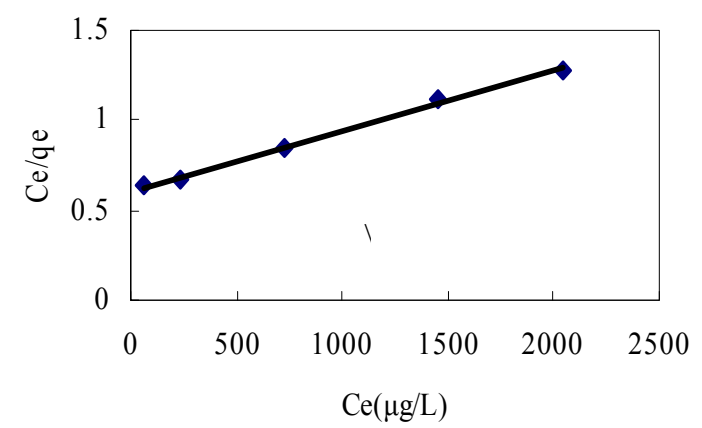

Figure 2. Simulated line of activated alumina adsorption. 
the adsorptive capacity extreme value and constant $b$ value can be obtained from the line intercept and line slope.

In Figure 2, the coefficient of determination was
0.9979, and the adsorption isotherm was the type of Langmuir. Based on the isotherm, the process of adsorption for phosphorus was predominant by single molecule adsorption. Then result was obtained as followed:

$$
\begin{array}{r}
\frac{1}{\left(q_{e}\right)^{0}}=0.0003, \frac{1}{b\left(q_{e}\right)^{0}}=0.6059, \mathrm{~b}=0.0005,\left(\mathrm{q}_{\mathrm{e}}\right)^{0}=3333 \mu \mathrm{g} / \mathrm{g} \\
\mathrm{q}_{\mathrm{e}}=\frac{\mathrm{x}}{\mathrm{m}}=\frac{V\left(\mathrm{C}_{\mathrm{i}}-\mathrm{C}_{\mathrm{e}}\right)}{\mathrm{m}}=\mathrm{b} \quad\left(\mathrm{q}_{\mathrm{e}}\right)^{0} \frac{\mathrm{C}_{\mathrm{e}}}{1+\mathrm{b} C_{\mathrm{e}}}=1.67 \frac{\mathrm{C}_{\mathrm{e}}}{1+0.0005 \mathrm{C}_{\mathrm{e}}}
\end{array}
$$

Finally, the adsorptive capacity of activated alumina was $3333 \mu \mathrm{g} / \mathrm{g}$.

\subsection{Experiment on Silica Sand}

The result was shown in Table 3 .

The result was obtained as followed:

$$
\begin{aligned}
& \frac{1}{\left(q_{e}\right)^{0}}=0.0205, \frac{1}{b\left(q_{e}\right)^{0}}=18.149, \mathrm{~b}=0.0011,(\mathrm{qe})^{0}=48.78 \mu \mathrm{g} / \mathrm{g} \\
& \mathrm{q}_{\mathrm{e}}=\frac{\mathrm{x}}{\mathrm{m}}=\frac{V\left(\mathrm{c}_{\mathrm{i}}-\mathrm{c}_{\mathrm{e}}\right)}{\mathrm{m}}=\mathrm{b}\left(\mathrm{q}_{\mathrm{e}}\right)^{0} \frac{C_{\mathrm{e}}}{1+\mathrm{b} C_{\mathrm{e}}}=0.054 \frac{\mathrm{C}_{\mathrm{e}}}{1+0.0011 \mathrm{C}_{\mathrm{e}}} .
\end{aligned}
$$

The adsorptive capacity of silica sand for phosphorus was $49 \mu \mathrm{g} / \mathrm{g}$.

The result showed that silica sand could adsorb phosphorus weakly, but its adsorptive capacity was far less than activated alumina.

\subsection{Experiment on Anthracite Coal}

The adsorption experimental result was shown in Table 4.

Table 3. Adsorption experimental result for phosphorus by silica sand.

\begin{tabular}{cccc}
\hline $\begin{array}{c}\text { Initial } \\
\text { concentration } \\
C_{i}(\mu \mathrm{g} / \mathrm{L})\end{array}$ & $\begin{array}{c}\text { Equilibrium } \\
\text { concentration } \\
C_{e}(\mu \mathrm{g} / \mathrm{L})\end{array}$ & $\begin{array}{c}\text { Adsorptive } \\
\text { capacity } \\
q_{e}(\mu \mathrm{g} / \mathrm{g})\end{array}$ & $C_{e} / q_{e}$ \\
\hline 100 & 79.25 & 4.15 & 19.09 \\
200 & 162.32 & 7.54 & 21.54 \\
300 & 247.89 & 10.42 & 23.78 \\
500 & 423.53 & 15.29 & 27.69 \\
800 & 689.02 & 22.20 & 31.04 \\
1000 & 879.98 & 24.00 & 36.66 \\
\hline
\end{tabular}

Table 4. Adsorption experimental result for phosphorus by anthracite coal.

\begin{tabular}{cccc}
\hline $\begin{array}{c}\text { Initial } \\
\text { concentration } \\
\mathrm{C}_{\mathrm{i}}(\mu \mathrm{g} / \mathrm{L})\end{array}$ & $\begin{array}{c}\text { Equilibrium } \\
\text { concentration } \\
\mathrm{C}_{\mathrm{e}}(\mu \mathrm{g} / \mathrm{L})\end{array}$ & $\begin{array}{c}\text { Adsorptive } \\
\text { capacity } \mathrm{q}_{\mathrm{e}}(\mu \mathrm{g} / \mathrm{g})\end{array}$ & $\mathrm{C}_{\mathrm{e}} / \mathrm{q}_{\mathrm{e}}$ \\
\hline 50 & 1.59 & 9.68 & 0.16 \\
100 & 3.29 & 19.34 & 0.17 \\
200 & 11.74 & 37.65 & 0.31 \\
300 & 46.04 & 50.79 & 0.91 \\
500 & 148.11 & 70.38 & 2.10 \\
1000 & 518.76 & 96.25 & 5.39 \\
\hline
\end{tabular}

Then result was obtained as followed:

$$
\mathrm{q}_{\mathrm{e}}=\frac{\mathrm{x}}{\mathrm{m}}=\frac{V\left(\mathrm{c}_{\mathrm{i}}-\mathrm{c}_{\mathrm{e}}\right)}{\mathrm{m}}=\mathrm{b}\left(\mathrm{q}_{\mathrm{e}}\right)^{0} \frac{C_{\mathrm{e}}}{1+\mathrm{b} C_{\mathrm{e}}}=3.48 \frac{\mathrm{C}_{\mathrm{e}}}{1+0.0348 \mathrm{C}_{\mathrm{e}}}
$$

Adsorptive capacity was $100 \mu \mathrm{g} / \mathrm{g}$.

More times of experiment for each filter media were conducted, results were similar to previous data respectively.

\section{Discussion}

\subsection{Adsorption Mechanism of Activate Alumina}

Experimental result demonstrated that activated alumina adsorption was consistent with the langmuir isotherm. Feng [7] reported that one type of activated alumina has large adsorptive capacity of $3950 \mu \mathrm{g} / \mathrm{g}$ for soluble ortho-phosphorus and it was in agreement with result of this paper. Ning [8] reported that activated alumina adsorptive capacity was higher than activated carbon, and it was 3-9 times as high as activated carbon, in addition, optimum $\mathrm{pH}$ value was 3-4. The adsorptive capacity would increase when temperature was higher, but the adsorption for phosphorus was a type of reaction of thermal relief.

The Langmuir adsorption theory states that no solid surface is even and smooth absolutely, there are a great quantity of convex points which attract ions. The atom and ion on the convex point have unsaturated chemical bond, and creat surface activated centers, which can adsorb the adsorbate. Every center trap only one adsorbate 
molecule. When surface activated centers were occupied completely, the adsorptive capacity reach the highest, so generally there is one layer absorbate molecule on the surface of adsorbent. Hua [9] indicated that when activated alumina was saturated, all of surface of micropore was deposited by adsorbate particle closely and tightly. Almost all micropores were not in conjunction longer and activated alumina would lose activation after saturation. Comparison of new and used activated alumina showed that new activated alumina had much more micropores and surface area than used.

The order of activated alumina adsorptive force for anion in water is followed:

$\mathrm{OH}^{-}>\mathrm{PO}_{4}{ }^{3-}>\mathrm{F}^{-}>\mathrm{SO}_{3}>\mathrm{Fe}(\mathrm{CN})_{6}{ }^{4-}>\mathrm{CrO}_{4}{ }^{2-}>\mathrm{SO}_{4}{ }^{2-}>\mathrm{Fe}(\mathrm{CN})_{5}{ }^{3-}$ $>\mathrm{Cr}_{2} \mathrm{O}_{7}{ }^{2-}>\mathrm{I}^{-}>\mathrm{Br}^{-}>\mathrm{Cl}^{-}>\mathrm{NO}_{3}->\mathrm{MnO}_{4}^{-}>\mathrm{ClO}_{4}^{-}>\mathrm{S}^{2-}$

It is apparent that activated alumina adsorptive force for phosphate anion is stronger than other anions, such as $\mathrm{SO}_{4}{ }^{2-}$ and $\mathrm{Cl}^{-}$, so activated alumina adsorb phosphate anion in predominance.

\subsection{Filter Media Comparison}

According to adsorptive experiment, the adsorptive capacity of activated alumina, silica sand and anthracite coal were $3333 \mu \mathrm{g} / \mathrm{g}, 49 \mu \mathrm{g} / \mathrm{g}$ and $100 \mu \mathrm{g} / \mathrm{g}$ respectively. Characteristic difference of three filter media are analyzed as follows, and represented in Table 5.

Porosity: It is different for every filter media. The porosity just represents the space between granules, not including inner micropore. It is micropore performing main adsorptive function instead of space between granules, so it is insignificant to compare the porosity of filter media to analyze the adsorptive capacity.

Micropore volume and pore size: The quantity of micropore decides the inner surface area, and pore size limit the dimension of attached molecules. Silica sand and anthracite coal have little inner micropore, therefore they don't have inner adsorption efficiency for phosphorus.

Surface area: In Table 5, adsorptive capacity is correlative to surface area. The specific surface area of activated alumina was larger than that of silica sand and anthracite coal. Xie [10] reported that when specific surface area was large, the adsorptive capacity would be large. Additionally it was proved that even if absorbent was the

Table 5. Comparison of every adsorbent.

\begin{tabular}{lcccc}
\hline Filter media & $\begin{array}{c}\text { Pore } \\
\text { volume } \\
(\mathrm{mL} / \mathrm{g})\end{array}$ & $\begin{array}{c}\text { Pore size } \\
(\mathrm{nm})\end{array}$ & $\begin{array}{c}\text { Surface } \\
\text { isoelectric } \mathrm{pH}\end{array}$ & $\begin{array}{c}\text { Specific } \\
\text { surface area } \\
\left(\mathrm{m}^{2} / \mathrm{g}\right)\end{array}$ \\
\hline $\begin{array}{l}\text { Activated } \\
\text { alumina }\end{array}$ & $>0.39$ & $1-100$ & 9.5 & $>300$ \\
$\begin{array}{l}\text { Silica sand } \\
\text { Anthracite } \\
\text { coal }\end{array}$ & 0 & -- & $0.7 \sim 2.2$ & 0.04 \\
\hline
\end{tabular}

same species, the adsorptive capacity would differ because of specific surface area.

The adsorptive efficiency of silica sand or anthracite coal was very low for soluble ortho-phosphate, because they were all pure solid without micropore. The adsorptive property was only influenced by outer surface area for these two materials. Xie [11] reported that silica sand with diameter from $0.5 \mathrm{~mm}$ to $1.2 \mathrm{~mm}$ had a little surface area, and the surface was charged negatively. The outer surface of them was flat without micropore under the test of EM reported by Zhang [12], so the adsorptive function was not considered when they were applied to water treatment process.

Surface charge: Surface of mineral and clay was charged negatively, so they can not adsorb the anion in water. But activated alumina surface attach numerous anion $\mathrm{OH}^{-}$, so the surface isoelectric $\mathrm{pH}$ value is higher than 7 , and it has capacity of ion exchange. The surface isoelectric $\mathrm{pH}$ value of silica sand is less than 7 , reportedly it is $0.7 \sim 2.2$ [13], so it is charged negatively. This is the part reason for these three filter media holding different adsorptive capacity for phosphorus.

\section{Conclusions}

Adsorptive experiments of activated alumina, silica sand and anthracite coal were conducted for phosphorus removal, and result showed that adsorptive capacity of activated alumina, silica sand and anthracite coal were $3333 \mu \mathrm{g} / \mathrm{g}, 49 \mu \mathrm{g} / \mathrm{g}$ and $100 \mu \mathrm{g} / \mathrm{g}$ respectively.

Effective adsorptive property of activated alumina for phosphorus results from three factors, firstly there are many inner micropore that silica sand and anthracite coal do not have. The second factor is that surface area of activated alumina is approximate $300 \mathrm{~m}^{2} / \mathrm{g}$ and much larger than that of silica sand and anthracite coal. Finally the surface isoelectric $\mathrm{pH}$ value is higher than 7 , but those of silica sand and anthracite coal are far less than 7 .

For the biological stabilization of tap water, in order to improve removal of phosphorus, the activated alumina could be considered as effective material to replace the traditional filter media, because in filtration process the activated alumina can remove more phosphorus relying on the adsorptive capacity. But undesirable factors exist for applicable feasibility of activated alumina, such as the frangibility, the difficulty of regeneration and high cost in running process.

\section{Acknowledgement}

This work was financed by National Key Technology R\&D Program (2008BAJ08B13-04), Beijing Supreme Talents Supporting Project (20071D0501700240) and Major Projects on Control and Rectification of Water Body Pollution (2009ZX07317-005). We thank the 
laboratory staffs of the laboratories of School of Environment and Energy of BUCEA.

\section{References}

[1] M. J. Lehtola, I. T. Miettinen, T. Vartiainen, T. Myllykangas and P. J. Martikainen, "Microbially available organic carbon, phosphorus and microbial growth in ozonited drinking water," Water Research, Vol. 35, No. 7, pp. 1635-1640, July 2001.

[2] J. Q. Sang, G. Z. Yu, X. H. Zhang and Z. S. Wang, "Relation between phosphorus and bacterial regrowth in drinking water," Chinese Journal of Environmental Science, Vol. 24, No. 4, pp. 81-84, April 2003.

[3] A. Dietze, U. Wiesmann and R. Gnirss, "Phosphorus removal with membrane filtration for surface water treatment," Water Science and Technology: Water Supply, Vol. 3, No. 5, pp. 23-30, May 2003.

[4] W. Nishijima, E. Shoto and M. Okada, "Improvement of biodegradation of organic substance by addition of phosphorus in biological activated carbon," Water Science and Technology, Vol. 36, No. 12, pp. 251-257, December 1997.

[5] D. L. Jiang, and X. J. Zhang, "Relationship between phosphorus and bacterial regrowth in drinking water," Chinese Journal of Environmental Science, Vol. 25, No. 5, pp. 57-60, May 2004.

[6] D. L. Jiang and X. J. Zhang, "Phosphorus in drinking water and it's removal in conventional treatment proc- ess," Chinese Journal of Environmental Science, Vol. 24 No. 5, pp. 796-801, May 2004.

[7] Q. Y. Feng, "Study on advanced treatment technique of phosphorus removal in drinking water," Master Dissertation, Beijing University of Technology, Beijing, 2007.

[8] P. Ning, C. L. Deng, H. P. Pu and L. M. Niu, “Adsorption of phosphate from water with activated alumina," Nonferrous metal, Vol. 54, No. 1, pp. 37-39, January 2002.

[9] N. B. Hua and Y. Z. Ruan, "Microstructures of active alumina reproduction by heat-treatment method," Journal of Fuzhou University (Natural Science Edition), Vol. 35, No. 1, pp. 81-84, January 2007.

[10] H. Xie, W. B. Jia and Z. G. Wu, , "Performance of activated aluminum oxide as a fluorine-removal agent," Journal of Huazhong University of Science and Technology (medical sciences), Vol. 34, No. 5, pp. 644-646, May 2005.

[11] S. B. Xie, J. S. Lou, Z. W. Xiong and Y. Q. Wang, , "Research on phenol removal by silica sand filter," China Water and Wastewater, Vol. 16, No. 8, pp. 8-11, August 2000

[12] X. H. Zhang, X. C. Xiang and Q. Y. Meng, "Study on a new filtration medium-activated anthracite coal and its filtration process," Water Purification Technology, Vol. 26, No. 1, pp. 54-57, July 2007.

[13] M. M. Benjiamin, R. S. Sletten, R. T. Bailey and T. Bennett, "Sorption and filtration of metals using iron-oxide coated sand," Water Research, Vol. 30, No. 11, pp. 2609-2620, November 1996. 